Columbia Law School

Scholarship Archive

2018

\title{
All Quiet in the Western (European Football) Front: Regulation of Football in the European Continent
}

Petros C. Mavroidis

Colulmbia Law School, petros.mavroidis@unine.ch

Follow this and additional works at: https://scholarship.law.columbia.edu/faculty_scholarship

Part of the Entertainment, Arts, and Sports Law Commons, European Law Commons, and the International Law Commons

\section{Recommended Citation}

Petros C. Mavroidis, All Quiet in the Western (European Football) Front: Regulation of Football in the European Continent, EUROPEAN UNIVERSITY INSTITUTE, ROBERT SCHUMAN CENTRE FOR AdVANCEd STUdIES, GLOBAL Governance Programme Working Paper No. RSCAS 2018/26 (2018).

Available at: https://scholarship.law.columbia.edu/faculty_scholarship/2348

This Working Paper is brought to you for free and open access by the Faculty Publications at Scholarship Archive. It has been accepted for inclusion in Faculty Scholarship by an authorized administrator of Scholarship Archive. For more information, please contact scholarshiparchive@law.columbia.edu. 

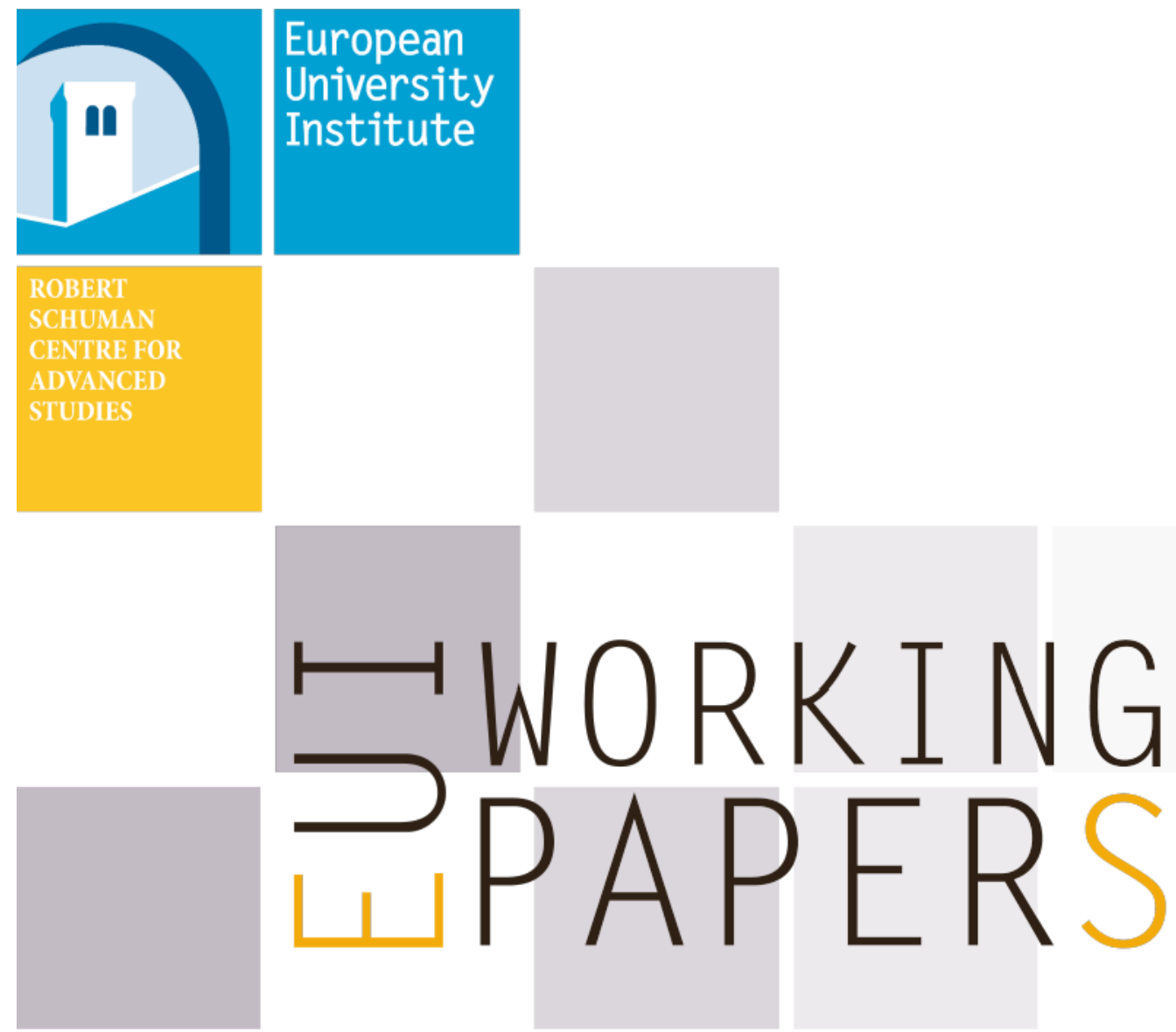

RSCAS 2018/26

Robert Schuman Centre for Advanced Studies Global Governance Programme-304

All Quiet in the Western (European Football) Front Regulation of Football in the European Continent

Petros C. Mavroidis 
European University Institute

Robert Schuman Centre for Advanced Studies

Global Governance Programme

\section{All Quiet in the Western (European Football) Front Regulation of Football in the European Continent}

Petros C. Mavroidis

EUI Working Paper RSCAS 2018/26 
This text may be downloaded only for personal research purposes. Additional reproduction for other purposes, whether in hard copies or electronically, requires the consent of the author(s), editor(s). If cited or quoted, reference should be made to the full name of the author(s), editor(s), the title, the working paper, or other series, the year and the publisher.

ISSN 1028-3625

(C) Petros C. Mavroidis, 2018

Printed in Italy, May 2018

European University Institute

Badia Fiesolana

I - 50014 San Domenico di Fiesole (FI)

Italy

www.eui.eu/RSCAS/Publications/

www.eui.eu

cadmus.eui.eu 


\section{Robert Schuman Centre for Advanced Studies}

The Robert Schuman Centre for Advanced Studies (RSCAS), created in 1992 and directed by Professor Brigid Laffan, aims to develop inter-disciplinary and comparative research and to promote work on the major issues facing the process of integration and European society.

The Centre is home to a large post-doctoral programme and hosts major research programmes and projects, and a range of working groups and ad hoc initiatives. The research agenda is organised around a set of core themes and is continuously evolving, reflecting the changing agenda of European integration and the expanding membership of the European Union.

Details of the research of the Centre can be found on:

http://www.eui.eu/RSCAS/Research/

Research publications take the form of Working Papers, Policy Papers, Policy Briefs, Distinguished Lectures, Research Project Reports and Books.

Most of these are also available on the RSCAS website:

http://www.eui.eu/RSCAS/Publications/

The EUI and the RSCAS are not responsible for the opinion expressed by the author(s).

\section{The Global Governance Programme at the EUI}

The Global Governance Programme is one of the flagship programmes of the Robert Schuman Centre for Advanced Studies at the European University Institute (EUI). It aims to: build a community of outstanding professors and scholars, produce high quality research and, engage with the world of practice through policy dialogue. At the Global Governance Programme, established and early career scholars research, write on and discuss, within and beyond academia, issues of global governance, focussing on four broad and interdisciplinary areas: European, Transnational and Global Governance; Global Economics; Europe in the World; and Cultural Pluralism.

The Programme also aims to contribute to the fostering of present and future generations of policy and decision makers through its unique executive training programme, the Academy of Global Governance, where theory and "real world" experience meet. At the Academy, executives, policy makers, diplomats, officials, private sector professionals and academics, have the opportunity to meet, share views and debate with leading academics, top-level officials, heads of international organisations and senior executives, on topical issues relating to governance.

For more information: http://globalgovernanceprogramme.eui.eu 



\begin{abstract}
Regulation of football in Europe is, absent some piecemeal interventions (like sharing of TV rights) largely non-existent. This is the case, because the de facto regulator (UEFA, Union Européenne of Football Associations) has no mandate to comprehensively address on its own competitive balance, the focal point of football, and, in more general terms, sports regulation. Various aspects of competitive balance are part and parcel of antitrust law. European Union (EU) law thus, comes into the frame, since this is the body of law regulating antitrust in the European continent. The European Union, nevertheless, has no mandate to regulate football comprehensively, even though it has the power to issue (non-sports specific) law (including competition law), which affects football, and UEFA must observe it. As a result, UEFA wants to but cannot regulate the hard core of sports regulation, whereas the European Union as is, cannot do much, and it is at best doubtful that it wants to anyway. Under the circumstances, because of the legislative conundrum, the "regulatory stalemate" we observe is probably the equilibrium point.
\end{abstract}

\title{
Keywords
}

Football regulation; UEFA Statutes: Support competence.

JEL Classification: K40 



\section{The Regulation of European Football Today*}

The commonplace view is that the European Union is the entity that intervenes and regulates not simply to address but also to preempt market failures, whereas the United States is a less "triggerhappy" player, placing its trust in markets. And yet, when it comes to football (sport), the tables are turned. The United States has put in place the most elaborate system aiming to promote competitive balance, whereas the European Union has stayed idle. The changing names of US champions in various sports are the best indication that the system is no fluke. The same teams appear in top positions routinely in the major European competitions.

In part, this is due to the fact that the European Union has not moved in seriously in the realm of sports regulation, as it has no comprehensive competence to regulate sport. This is left to national football associations, which retain autonomy to regulate football at the national level, while respecting certain minima that they jointly agree upon at the UEFA (Union of European Football Associations)level. UEFA is the regional association comprising national associations belonging to the European Union (majority), and associations from a few other European and Eurasian countries.

UEFA as well, is constrained by an idiosyncratic political economy, as it navigates between satisfying national football associations (its de jure clients), and football clubs (its de facto clients), idiosyncratic membership (as non-EU football associations participate as well), and the fact that it must observe FIFA (Fédération Internationale of Football Associations) law, as we explain later. ${ }^{1}$

Recently, nevertheless, UEFA has been announcing its desire to establish competitive balance across football clubs coming under its jurisdiction. It has not announced how it will achieve this objective. If US sports regulation could serve as example, then one or more of the instruments used there (salary cap, income sharing) will have to find application in some form in the European context as well.

Irrespective of the precise design to achieve competitive balance, ${ }^{2}$ UEFA will need the European Union and vice versa to do as much. The former has a comparative advantage when it comes to understanding the specificities of the football market, and it has in place some legislation that provides the background for seriously addressing competitive balance. It must of course, respect (for the reasons we explain later) the laws of the latter from which it simply cannot contract out. The European Union, on the other hand, has comparative advantage in understanding its laws that are applicable to football as well, has the institutional checks and balances that will provide the endeavour not only with the necessary intellectual- but also democratic legitimacy, but it has no mandate to regulate football within the European market.

Current practice regarding cooperation between the two actors does not lend to hope. There are cases of cooperation, even though informal, as there are (many more) cases of genuine conflict. Worse, there is uncertainty regarding resolution of future conflicts. The Court of Justice of the

\footnotetext{
Alasdair Bell, Jacques Bondallaz, Danilo Facchinetti, Nejat Haciömeroglou, Mislav Mataija, Alexander J. Philipps, Pablo Rodriguez, Andrea Traverso, Stephen Weatherill, Joseph H.H. Weiler, and Jan Wouters, very kindly shared their expertise on the issues discussed here with me and commented on prior drafts. Kirtikumar Mehta and Damien J. Neven deserve special praise, since, as always, did not tire to respond to my incessant questions, and correct my many misunderstandings regarding EU antitrust practice. Remaining errors are, of course, their own.

1 Taylor and Lanfranchi (2015) discuss the history of UEFA comprehensively.

2 Understanding the term "competitive balance" evades the purposes of this paper. Leeds and von Allmen (2016) offer a comprehensive discussion to this effect, looking into US practice and explain how this concept has been instrumentalised. The contribution of instruments like the salary cap etc. is often assumed, as it is quite difficult to establish the counterfactual in US sport. Be it as it may, the conventional wisdom is that similar instruments have played a constructive role in establishing a competitive balance in US sport.
} 
European Union (CJEU), as we explain later, has decided that there is no category of UEFA statutes that escapes its scrutiny, even though, it might decide against application of EU law in specific cases. It is hard to predict the outcome though, because of the test the CJEU will employ to this effect: "sports specificity" suffers from various unknowns, not least from amorphous notion of "proportionality", a legal concept that is employed not in quantitative, but in qualitative terms.

The current insecurity is a factor impeding regulation. And there are good arguments in favour of regulating in order to establish competitive balance, and contribute to the unpredictability of the sporting outcome, an objective that the CJEU has recognized is worth pursuing.

Let us revert once again to regulation of US sports, and use NBA (National Basketball Association) as illustration for our point. Revenue sharing, salary cap, and a drafting regime aiming to allow the weaker teams pick the stronger players are in place. It is difficult (if not impossible altogether) to know how much this regime has contributed to addressing competitive balance. The counterfactual is quite hard to establish. Presumptively though, this regime has contributed somewhat to that end. The changing identity of champions is an appropriate proxy to draw this conclusion.

We are of course, one step back in the European continent, as we are still discussing the prerequisites from moving down this road. There are various options that actors can contemplate about. Assuming the current distribution of competences is maintained, one could envisage an allencompassing sports-specific regulation, that could also insulate football from antitrust prosecution. A less far-reaching alternative would be to request for a formal antitrust exemption and/or a "comfort letter". ${ }^{3}$ Since the latter approach cannot cover areas other than antitrust, a complement will be necessary to address issues relating to the four freedoms of the European Union.

The level of ambition cannot be prejudged at this stage, and it will undeniably have an effect on the choice. The choice could also be affected by a change in the distribution of competences within the European Union. If sport became, for example, shared competence, then the question would arise whether action at the member state- or the EU-level was warranted.

Because of these unknowns, we will not rank the options presented. Our preference is for formal solutions, which we believe are the necessary ingredient for regulation of football in the European continent.

In Section 2, we discuss the origins of the regulatory authority to regulate football of the European Union (EU), and of the UEFA (Union of European Football Associations), the two main actors. In this Section, we deal with an explanation why the mandates of the European Union and UEFA are overlapping, and also why UEFA statutes must be construed in a manner that observes EU law.

Section 3 discusses practice. Here, we will show how on occasion cooperation was achieved, and when conflict was the ultimate outcome. We will attempt, the difficulties associated with this exercise notwithstanding, to show why cooperation has failed.

In Section 4, we advance possible solutions to address the problems caused. In this Section we also explain that absent a culture of cooperation, the quest for competitive balance might be at peril.

Section 5 recaps the main findings.

\section{One De Facto-, and One "Shadow" Regulator}

The European Union and UEFA started from totally different perspectives. The first, following a functionalist approach, in its earliest incarnation, was supposed to avert a third world war, before

Formally, no comfort letters can be issued anymore, as we explain later. The Commission can still issue decisions coming close to what used to be a "comfort letter". 
establishing a common market (where production factors would circulate freely), a monetary union, and eventually a political union as well. The second, was supposed from Day One to organize and administer international football competitions within Europe.

The description of their respective mandates brings us awfully close to understanding the European Union and UEFA as two ships passing by in the night. And yet, nothing could be further from truth, since they ended up stepping on each other's toes. Here is why.

\subsection{Football Regulation in EU Law}

Weatherill (2017) signed the definitive work on EU competence when it comes to football, and sports in more general terms. We could sum up his findings as follows. The European Union has only support competence ${ }^{4}$ to regulate sports, but a substantial part of its law, although not sport-specific, concerns sports and has been applied to football- and other sports-related cases. The first footballrelated cases are decisions by the Court of Justice of the European Union (CJEU) sanctioning originbased domestic statutes that were applicable to athletes. Eventually cases of alleged de facto discrimination were brought before the CJEU as well. Whereas most of the practice before the CJEU concerns free movement of production factors, relevant practice before the Commission has very often concerned EU antitrust law and policy.

This much concerns formal disputes. The European Union has on occasion resolved issues with the UEFA in informal manner. The legal value of similar "resolutions" is dubious, if not shaky altogether (since even formal Commission decisions do not bind the CJEU). Still, the two main actors have had recourse to similar solutions in order to address important legislative initiatives that the UEFA has undertaken.

\subsubsection{The Objective Function of the EU Integration Process}

Karel van Miert, a former EU Commissioner for competition, used to quip that the framers of the EU integration process had no intention to establish a common market of football. The objective function of the EU integration process is to create a space where production factors would circulate freely (and reap the ensuing economic benefits). There was no mention of sport in the original statutes at all, and sport did not appear in the EU statutes until much much later in the integration process.

\subsubsection{Sport in the European Union}

To understand how the EU treaties regulate sport one has to look into different legislative sources and practice. $^{5}$

Head on, Article 165 of the Treaty on the Functioning of the European Union (TFEU) makes it clear that sport is a "support" competence. The EU Member states retain the competence to regulate sport (and football, of course). The Commission can adopt initiatives to support initiatives by the Member states, without preempting their competence. ${ }^{6}$ This is not where the relevance of EU law to football stops, though.

\footnotetext{
4 Article 165 of the Treaty on the Functioning of the European Union (TFEU) is the legal basis. The term "support competence" denotes that it is Member States that are, in principle, competent to regulate sport (football), the European Union limiting itself to interventions that will not preempt, but that will support their exercise of competence in this area.

5 This section draws heavily on Weatherill (2017).

6 The allocation of competences to the EU authorities is function of the principle of "conferral" (Article 1 of the Treaty on the European Union, TEU). EU competences exist to the extent that its Member states have voluntarily transferred them from the state- (where they originate) to the EU-level.
} 
In a series of CJEU and Commission decisions, it has been made amply clear that both EU antitrust law, as well as the provisions on the free movement of production factors apply to football as well (scope), subject to "sports specificity" (standard of review).

As to the scope, the CJEU has left no doubt that, in principle, it has jurisdiction over any measure adopted by UEFA (and sporting associations, in general). This is what the notorious Meca-Medina judgment amounts to, and we will return to it later. At the same time, the CJEU has also clarified that the degree of deference it will be adopting will depend on the facts of the case. It will be asking whether proportionate means have been employed to attain a legitimate objective. This is what "sports specificity" amounts to. To the extent thus, that the EU authorities deem an objective pursued by a sports entity to be legitimate, they will not put into questions UEFA actions to realize it, if the means employed are proportional (necessary) to the ends.

In practice this means that the EU authorities and UEFA have dealt with the same issues. They have both had to review issues as divergent as nationality of players, transfer periods, transfer fees, location of games, responsibility to organize games, licensing of agents, licensing of clubs, overspending by clubs, TV rights, to name the highest profile cases treated so far.

The difference is that whereas UEFA has taken the lead to regulate (in the absence of a comprehensive mandate allowing the European Union to comprehensively regulate sport, UEFA has emerged as the single de facto regulator of football in the European continent), EU authorities (the Commission and the CJEU) have moved in and addressed the consistency of similar interventions with EU law. We explain why EU law trumps UEFA law in what now follows.

\subsection{Football Regulation at the UEFA-Level}

To understand UEFA at work, we need to first examine the scope of its regulatory authority. This inquiry in turn, obliges us to first look into who has transferred what authority to UEFA.

\subsubsection{What is UEFA?}

Both the EU authorities, ${ }^{7}$ as well as literature consistently treat UEFA as a cartel. ${ }^{8}$ And yet, while this taxonomy is the safe way for subjecting UEFA to the applicability of EU antitrust rules, it is probably a reduction when compared to truth.

In fact, it is national football associations, based in independent countries recognized by the United Nations that are its members (Article 3 of UEFA Statutes). These entities in turn, are often vested with (public) authority to regulate football within national frontiers. ${ }^{9}$ UEFA exhibits a more "private" face as well: it is in constant discussion with football clubs and their association (ECA, European Clubs Association), and it is with them in tandem that it de facto regulates football. ${ }^{10}$

Consequently, following Mataija (2016), we would characterize UEFA as public-private partnership, a forum where public authority and private interests meet.

7 The first official pronouncement to this effect was by Advocate General Lenz in the Bosman litigation before the CJEU.

8 Technically, its decisions have been called "decisions of associations of undertakings", and on occasion, UEFA has been assimilated to a single entity occupying a dominant position, see, for example, the Piau decision of the general Court as well as the CJEU, T-193/02, and C-171/05.

9 Some are pure private entities, but some are legal entities of public law.

10 Clubs are not members of UEFA. Furthermore, clubs' interests do not coincide with those of their national associations. Big clubs in national associations would rather find a modus vivendi with big clubs from other national associations on the face of evidence suggesting for example, gains from participating in Champions League, rather than strengthen weaker clubs in their own association. 


\subsubsection{UEFA at Work}

The legislative mandate of UEFA is not clearly delineated in its statutes. It is essentially function of its objectives, which appear in Article 2(a) of the UEFA Statutes:

To deal with all questions relating to European football

This is textbook definition of "all-encompassing" since, in principle, it will be hard to draw an exhaustive list of everything that relates to European football. Occasionally, there is some specificity, like in Article 2(d), which states that UEFA has the right to:

organize and conduct international football competitions and tournaments at European level ...

while respecting the players' health

Similar examples are scarce, though. And anyway, when UEFA does not find a specific legal basis to base its actions, it can always go back to Article 2(a) cited above.

This provision does not make a distinction between "sporting"- (e.g., number of players per team; offside rules, etc.) and "business" law-making. It gives it carte blanche to regulate it all. The UEFA has not drawn a distinction in practice, as it has moved in to regulate not only say the Champions League competition (when/where games should be played), but also Financial Fair Play (clubs should not overspend their income, the composition of which a UEFA statute defines).

UEFA is not formally a member of FIFA. Its member associations are. Since its member associations have to respect FIFA statutes and secondary law, UEFA must do the same. ${ }^{11}$

\subsection{Why UEFA Must Respect EU Law}

According to Article 5.1 of the UEFA Statutes:

Membership of UEFA is open to national football associations situated in the continent of Europe, based in a country which is recognised by the United Nations as an independent state, and which are responsible for the organisation and implementation of football-related matters in the territory of their country.

National football associations are sometimes branches of national governments, and sometimes legal persons of private law. To the extent they revert a "public" character, they must observe the duties that Member states have. This is of course, true for national football associations of Member states. To the extent that they are private entities, they must anyway respect EU competition law, and the four freedoms because of the quasi-regulatory nature of their output. National football associations of member states must anyway observe as much. Foreign national football associations might have to incur this obligation if their actions have "qualified effects" in the EU market. ${ }^{12}$

Almost 2/3 of the UEFA Membership (35/55 to be precise) are either members of the European Union (31 of them, since the United Kingdom encompasses four distinct football associations), or are members of the EU customs territory (Andorra, Gibraltar, San Marino), or have special relationship with the European Union (Faroe Islands).

Members of the European Union are also under a very elaborate duty of cooperation (Article 4.3 of the Treaty on the European Union, TEU), which obliges them to take all appropriate actions (and also

11

Lindström-Rossi et al. (2005), commenting on the Piau case (T-193/02) have expressed the view that FIFA has not been conferred the authority to regulate business-related issue, as is the case for example, with National Bar Associations. Similar powers can be conferred only if the FIFA members possess them in the first place. As we explain later though, the FIFA members which belong to the European Union cannot contract out from their obligation to observe EU law.

12 A detailed discussion of the "effects" doctrine as understood by the CJEU exceeds the purposes of this paper. The most recent CJEU decision on this score is Intel, C-413/14. The opinion of the Advocate General, Nils Wahl, is equally (if not, even more) interesting to read. 
avoid taking obstructing actions) to further the objectives of the European Union. This obligation is relevant for national football associations that revert a public character. Finally, Members of the European Union must submit exclusively to the CJEU all disputes regarding the interpretation of EU law. ${ }^{13}$ Since a lot of EU law affects football (competition, free movements), and since the CJEU in its notorious Meca Medina judgment (C-519/04P) has subsumed, in principle, all decisions by sporting authorities to the control of consistency with EU law, this obligation, it is easily understood, is quite comprehensive.

A short digression is warranted here. The distinction between "sporting"- and "business" rules is not shorthand for assigning competence to UEFA for the former and the EU authorities for the latter. As we have briefly stated above, the CJEU in its Meca-Medina judgment held that even sporting rules (in this case, antidoping regulations) will be scrutinized. ${ }^{14}$ The CJEU might decide against applying EU law on them if they pursue a legitimate sporting objective and employ means necessary to attain it, as we explain later.

It is thus, difficult to see how UEFA output can ever evade the control by the EU authorities. In this sense, the separation between sporting- and political issues, an issue to which we turn in what now follows, should be understood in the most narrow terms, and not as carte blanche to avoid the "bite" of EU law.

\subsection{Separating Sports from Politics}

The separation of football from politics has become one of the flagships of FIFA. It should not be understood though, as some sort of platform to understand regulation of football by FIFA/UEFA as a self-contained regime, for the reasons discussed in what now follows.

FIFA (Fédération Internationle of Football Associations) has enacted provisions aimed at eliminating political influence on its members. Although UEFA is not formally a member of FIFA (UEFA members are members of FIFA), there is no doubt that it is bound by FIFA statutes. After all, UEFA is the sum of entities that must observe FIFA statutes.

Why did FIFA move into this direction? Miège (2000) catalogues political intervention to national associations much before the FIFA intervention. FIFA was definitely not after a witch hunt. The question is of course, how far we should take the idea that football associations should not be subjected to political influence. For the reasons mentioned below, we suggest a very narrow construction of this provision, otherwise one might end up construing FIFA/UEFA membership as legitimate deviation from EU law. This can never be the case, for the reasons already discussed above. $^{15}$

FIFA has in place a series of provisions aiming to implement the firewall between political influence and football regulation. As per Article 14, its members must:

manage their affairs independently and ensure that their own affairs are not influenced by any third parties in accordance with art. 19 of these Statutes;"

Article 19 in turn defines independence, asking in the first paragraph the following:

Each member association shall manage its affairs independently and without undue influence from third parties.

13 The recent opinions of the CJEU in the cases $2 / 13$ and 2/15 have put this point beyond doubt.

14 This finding has been further underlined in MOTOE(C-49/07).

15 Szymanski and Zimbalist (2005) recount a very comprehensive discussion of the organization and regulation of cricket in the United Kingdom, which could serve as guidance for those enacting sports statutes. 
Now, this might look like a far-reaching provision, asking effectively from its members to avoid any interference, and concentrate in implementing the FIFA mandate. The following paragraphs though, leave no doubt that the kind of political interference envisaged here is confined solely to elections of officials serving in national associations.

Thus, one should not understand this provision as an attempt to construe FIFA/UEFA law as selfcontained regime. It should not be understood either as an addition of FIFA (sports regulator) to the administrative state, away, that is, from democratic control. It is simply a safeguard to ensure that national associations will be composed of democratically elected officials.

\subsection{The Spider and the Fly}

The UEFA thus, emerges from the discussion above as the de facto regulator of European football. There is a "shadow" regulator though, hiding behind the scenes: the European Union. Although it has no comprehensive mandate to regulate football, it has mandate to regulate its internal market. Since football as business is part and parcel of the European internal market, it comes under the disciplines of the internal market, albeit with the adjustments that "sports specificity" dictates.

UEFA has been equated from Bosman ${ }^{16}$ onwards a cartel or an enterprise with dominant position in the EU market. Hence, all its actions will be scrutinized anyway under competition law. To the extent that its actions affect one or more of the four freedoms of the EU internal market, they will be scrutinized under that heading as well. This latter scrutiny is equally very probable, since in equilibrium the working of the internal market will be affected, at least potentially or indirectly, by the overwhelming majority of UEFA activities.

UEFA thus, must respect the web of legislation that the EU institutions have put in place. Inevitably, it will fly in. Past experience, to which we now turn, amply proves this point.

\section{Cooperation and Conflict (Or is it the Other Way Round?)}

In what now follows, we first explain at aggregate level the manner in which discretion has been exercised by the two actors, the management of the ensuing conflicts, and also inquire into (some of) the reasons that gave birth to the conflicts.

\subsection{How Has Discretion Been Exercised?}

For most authors that have written extensively on this issue, ${ }^{17}$ the Bosman jurisprudence ${ }^{18}$ emerges as the absolute catalyst in the relationship between football authorities (UEFA/FIFA) and the European Union. In a way, this is deservedly the case. High-profile football institutions (like the payment of transfer fees at the end of contracts; the number of foreign players allowed per team) were dismantled.

Following this dispute, UEFA showed its willingness to negotiate its legislative initiatives with the EU authorities, and the EU authorities stressed the primacy of EU law (Meca-Medina being the apex of similar pronouncements) while acknowledging "sports specificity", that is, the need to accommodate sport within its rules (or, better, adjust the application of the latter to the specificities of the former).

In five documents of varying legal value (Amsterdam Declaration, 1997; Nice Declaration, 2000; Commission White Paper on Sport, 2007; Lisbon Treaty, 2009; Commission Communication, 2011),

\footnotetext{
16 We discuss this CJEU jurisprudence later.

17 Parish (2003), García (2007), Weatherill (2017) and many more.

18 C-415/93.
} 
the EU authorities acknowledged sports specificity, that is, the need to mitigate the implementation of EU law in order to sufficiently take into account the special characteristics of sport: unlike other markets, sports is not a zero-sum game, since strength of all participants is the key in inciting the overall interest. Indeed, the very product of sport competition cannot be produced absent the simultaneous presence of competitors in the "market". The need to guarantee the unpredictability of the outcome, a legitimate sporting objective the validity of which has been acknowledged by the EU institutions, is further argument in favour of intervening in order to promote competitive balance across competitors. $^{19}$

In Europe more especially, a pyramidal structure has been in place, and football is not played between teams comprising both men and women. Furthermore, for football to be played in functional number, only a limited number of players can be fielded each time. As a result, adjustments to nondiscrimination provisions, prohibition of quotas, and implementation of antitrust might be warranted.

Thus, good will to cooperate was present both in Brussels as well as in Nyon, the headquarters of the European Union and UEFA respectively. And yet, cooperation has not been a consistent theme throughout the post-Bosman years, and the quest for harmonious outcomes that would simultaneously satisfy the EU- as well as the UEFA authorities has not been always achieved.

\subsection{Overlapping Mandates in Practice}

In what follows, we do not purport to provide a comprehensive account of all football (sport) cases that have been discussed by EU authorities, either at the Commission- or the CJEU-level (or both). Weatherill (2017) has done that. Rather, we want to provide a few examples of cooperative as well as uncooperative behaviour to illustrate the at times uneasy relationship between UEFA and the European Union.

We distinguish between cases of direct and indirect conflict and/or cooperation depending on the origin of the transaction we discuss. Direct conflict would encompass cases where EU authorities and UEFA were at loggerheads because of a sporting issue, where indirect conflict would capture cases where the two disagreed in areas not necessarily of sporting nature. We then proceed to review the corresponding cases where cooperation was achieved.

\subsubsection{Direct Conflict}

Besides Bosman, UEFA and the European Union have been at loggerheads a few times.

The most notable of cases of direct conflict is the dispute between UEFA and the Commission regarding the characterization of football matches as items of general interest (C-201. 204, 205/11). The heart of the dispute concerns the Audiovisual Media Services Directive. Member states were allowed to decide which games are of "general interest", and, consequently, allow free to air transmission. Belgium and the United Kingdom held that all matches of a World Cup were of general interest. UEFA disagreed with this characterization as it would undermine the potential for increasing TV income by selling those matches to Pay TV.

19 This much is acknowledged in US practice, probably the most liberal across important markets. In US antitrust "dominant" companies are under no special duty to behave in particular manner. US antitrust authorities have treated them in the same way as they have treated minnows. Still, when it comes to sports regulation, US legislator has gone out of its way to ensure that the likelihood to have "dominant" players is reduced, and hopefully, eliminated altogether. Whereas absolute paritas armis does not exist, sports competitors in most US sports can lawfully employ similar means to attain sporting success. 
The CJEU, for all practical purposes, held that there was nothing wrong with the decision of the two EU Member states. The Commission would perform a limited review of their discretion to characterize games as events of "general interest". ${ }^{20}$

\subsubsection{Indirect Conflict}

In 2016, in case 40023 (Paramount), ${ }^{21}$ the Commission dealt a first but decisive blow against territorial protection of TV rights in a dispute unrelated, but highly relevant to football, and sports in general. It is easy to understand that market segmentation (by assigning territorial protection for TV rights) increases the profits of TV services suppliers, and in turn the premium that UEFA can lawfully request from them for the same TV rights.

Paramount had requested from Sky TV to block, through its decoders, access to films sold to Sky for use outside UK/Ireland (this is the so-called "geo-blocking"). Paramount had further requested from Sky not to respond positively to requests to unblock transmission to territories beyond which territorial protection had been paid for ('passive sales').

The EU Commission imposed binding commitments on Paramount, whereby the latter accepted to stop imposing the latter obligation ('Paramount obligation'), and to allow Sky TV to decide whether to accept passive sales ('Broadcaster obligation').

Following this decision, the Commission has circulated a draft Regulation proposal (COM (2016) 289) aiming to crystallize this case law into law. This is of course, part and parcel of the "single digital market" aiming to create one single digital space across EU Member States. When realized, there will, in all likelihood, be no more room for territorial protection (geo-blocking).

\subsubsection{Indirect Cooperation}

The Commission decision on ENIC (COMP/37) is an appropriate illustration. ENIC (English National Investment Company) owns various clubs in Europe participating in different national championships. UEFA disallows multiple ownership of clubs participating in UEFA-sponsored competitions. Following litigation before CAS (Court of Arbitration of Sports), UEFA prevailed.

ENIC initiated new proceedings before the EU Commission. The EU Commission held that the measure did restrict competition, but that it was meant to serve a sporting legitimate objectivity, namely, preserve the integrity of sporting competitions. Since the measures employed to this effect were judged proportional, in that, multiple ownership was not more restrictive than necessary to preserve integrity of sporting competitions, the EU Commission effectively sided with the UEFA by rejecting the complaint lodged by ENIC.

\subsubsection{Direct Cooperation}

Three of the most important initiatives by UEFA have been discussed and "settled" informally with the Commission.

Home grown players is a UEFA initiative aiming to favour vertical integration of football clubs. $8 / 25$ football players appearing in the list of players that is communicated to UEFA each year by clubs participating in its competitions should be home grown, in the sense that four of them should have spent three years at least between the age of 15 and 21 at the club, and four of them should have done

\footnotetext{
20 In a subject-matter wise related case, the Commission obliged UEFA to rework the package for collective sale of TV rights (IV 37.398). The UEFA Statutes make it crystal clear that UEFA (along with its member associations) has the right to exploit TV rights for all games that it organizes (Articles 42, 47, and 48).

21 http://europa.eu/rapid/press-release_IP-16-2645_en.htm
} 
the same in clubs belonging to the same association. The measure could qualify as de facto discrimination, since chances are it favours domestic over foreign players. And yet, the EU Commission found that it pursues a legitimate objective and is not more trade restrictive than necessary. ${ }^{22}$

UEFA also undertook an initiative aiming at conditioning licensing of clubs (license being necessary to participate in UEFA-sponsored competitions). Clubs would not receive a license unless if they demonstrate adequate management of the club, training facility for youth, economic and financial stability, and finally, ensure that their football stadium meets certain specified safety standards. This measure raised competition-related worries (restriction of number of players in a market), freedom of investment related worries (fewer clubs available to buy, and freedom of movement of workers related worries (fewer clubs to play for). The European Parliament pronounced in favour of the measure (P6_TA(2007)0100). The European Commission did not adopt a position, but has, through its attitude and the lack of challenge so far, shown acquiescence.

Following widespread reports evidencing the over-indebtedness of some dominant football clubs, UEFA adopted an initiative to curtail spending, and link it to income made, making thus spending sustainable in the medium run at least. ${ }^{23}$ The ensuing FFP (Financial Fair Play) has been criticized for being inconsistent with EU competition law, as well as the free movement of capital. In a joint statement between Commissioner Almunia and UEFA President Platini, the common position adopted was that FFP contributes to rationalizing investment in football clubs, and the urge was expressed to implement it in proportional manner. FFP is in its fifth year of implementation now, and the EU authorities have yet to mount a legal challenge against it, implicitly thus, acquiescing to its proportional nature. ${ }^{24}$

The solutions above are informal, and there is no guarantee that the Commission will not in the future challenge one (or more) of them. Indeed, informal settlements bind neither the Commission, nor the CJEU, not national courts called to apply Article 101 of the TFEU. The Commission could have been bound had it issued a "comfort letter" 25 or had it exempted a practice through recourse to Article 101.3 of the TFEU. The CJEU is not bound by Commission's decision to this effect.

Nevertheless, with the passage of time, the Commission challenging these measures is becoming a remote likelihood. All the more so, because of the documents of varied legal force we have cited in 3.1.5 above.

\subsection{Cooperation is Not Necessarily Resolution}

The discussion so far shows that conflicts have not been avoided in the post-Bosman era, when the CJEU held that mainstays of football regulation were inconsistent with EU law. But even when cooperation has been achieved, as in the cases discussed under 3.2.4 above, it is not watertight, cemented agreements we talk about. Uncertainty still looms, and uncertainty is not helpful.

22 SEC (2011) 66 of 18 January 2011.

23 FFP is not about establishing competitive balance, even though this is on occasion portrayed as such in literature. There is by now empirical evidence supporting this view, see the Final Report to the DG Education, Youth, Culture and Sport of the European Commission, entitled "An Update on Change Drivers and Economic and Legal Implications of Transfers of Players", European Union Publications, Luxembourg, March 2018, available at https://ec.europa.eu/sport/sites/sport/files/report-transfer-of-players-2018-en.pdf

24 Daniele Striani, a football agent, complained that FFP distorts competition. He lodged a complaint before a Belgian court that requested a preliminary ruling from the CJEU. This request was turned down, since the CEUJ held that its responses were not necessary for the resolution of the dispute before the Belgian court, see OJ C 2015 270/19. Note also that Downward and Pearson (2014) have argued that de facto in Bernard (C-325/08), the CJEU supplied a few good arguments in favour of the compatibility of the hone-grown player rule with EU law.

25 Until the time when issuance was possible. This is not the case anymore, as we discuss later. 
There is uncertainty regarding the legal status under European law of the initiatives undertaken by UEFA. UEFA has in place initiatives like the FFP, its licensing schemes, the home-grown rule, that have not yet received the definitive "green light" from the EU authorities.

There is further uncertainty regarding the status of initiatives undertaken by members of UEFA members, to be precise: the ECA (European Clubs Association) is the successor of the G14 that gave birth to the notorious "Gandalf project". Media Partners International (MPI), a consortium representing the interests of the top clubs in European football, had notified the Commission under Article 14 of Regulation 17/2003 of its resolve to establish a European Football league (EFL). ${ }^{26}$ EFL would be a league with closed membership, that is, it would contravene head on the current promotion-relegation system reigning through European football.

The project has since been abandoned. One might legitimately speculate that it was a ploy to extract concessions from UEFA for the big leagues in the European Union. Nevertheless, the question regarding the consistency of closed football leagues with the EU law persists, as it has not been resolved in definitive manner. In the absence of a formal ruling condemning closed leagues, a breakaway league, like the "Gandalf project", is very much a continuing threat weakening the UEFA bargaining position in its relations with the ECA.

So far, UEFA has not submitted any request for exemption from antitrust rules. This is precisely what some US professional leagues have done in order to consolidate their regulatory interventions. True, the Commission can always hide behind the directly applicable, nowadays, character of Article 101.3 of the TFEU. Equally true though, this does not mean that the Commission cannot issue exemptions anymore. We will return to this question in what follows.

\subsection{Conflict Can Arise for Legitimate Reasons}

Why have we observed conflicts so far? There are of course, dozens of potential reasons, and, essentially since those possessing privately information might have no incentive to reveal it, we might never know why this has been the case.

Recall that, for the reasons discussed above, it would be premature to exclude areas of UEFA law from scrutiny under EU law. So, as things stand, it all boils down to the implementation in practice of "sports specificity", the test that will help EU institutions distinguish wheat from chaff. ${ }^{27}$

\subsubsection{The Inherent Indeterminacy of "Sports Specificity"}

The "sports-specificity" test is essentially an exercise in proportionality. To decide whether a means is proportional to stated ends, two conditions must always be present:

(a) More than one means can reach the stated ends;

(b) One of the two alternatives imposes less of a burden on the protected value (in our case, the EU integration process).

To satisfy condition (a), the judge has to persuade itself about the legitimacy of the ends sought. In constitutional structures, the judge might put into question the invocation of an objective. Not so, in all other contexts. This is why it is condition (b) that matters.

To respond to the question asked in condition (b), measurement is required. Someone has to quantify the effects of each alternative measure to the protected value. Take FFP as example. UEFA's

\footnotetext{
26 COMP. 37400.

27 Szyszczak (2018) notes the recent proliferation of cases concerning sports before national competition authorities, which as well will be called to apply this test whenever they adjudicate similar disputes.
} 
stated objective through its enactment has been to oblige clubs to live within their means and thus, avoid unsustainable models of sporting improvement that run comport "sporting"- (e.g., clubs going bankrupt halfway through a competition) and/or "moral" (e.g., buying instead of fighting for success) negative externalities. Assuming, and this is a reasonable assumption, that the EU institutions buy into this claim, they will ask whether FFP was indeed the least restrictive means to attain the objective, or, conversely, whether another option imposing less of a burden on the EU internal market could have been reasonably employed to this effect.

Courts, and the CJEU is no exception to that, routinely favour "qualitative" over "quantitative" factors. This is of course, absurd. How can they evaluate the restrictiveness on the EU internal market absent some quantification of the effects of FFP? The only reasonable conclusion they can come to would be some sort of impressionistic account presumptively leading them to believe that FFP is less of a burden than say bank guarantees that are renewed periodically.

And this is exactly what happened. When reading the informal settlement on FFP one can only marvel at the amount of generic, open-ended language contained therein. The Commission agrees that FFP is proportional to stated ends (without discussing alternatives), and further encourages its implementation if the latter continues to observe proportionality. Go figure.

Reliance on exclusively factors is not necessarily bad news for the sports regulator, in our case, UEFA. For starters, it absolves it from the obligation of engaging into elaborate econometrics to show that FFP is proportional indeed. The problem, nevertheless, is that UEFA cannot know ex ante what the outcome of the assessment by EU authorities will be. Quantitative analysis can yield at the very least a ballpark estimation, depending on what the range of elasticities looks like. Qualitative analysis is like entering into a foggy area, often surrounded by (impenetrable) mist.

As if this was not enough, the judge might have to ask one additional question when discussing proportionality: is it feasible to employ the least restrictive means? Courts that understand this test as implying that ends are not justiciable, have consistently inquired into the "reasonable availability" of the least restrictive option. ${ }^{28}$ It is, at this stage at least, unclear whether a similar test will also be employed whenever the EU authorities are called to apply sports specificity.

With this in mind, let us now revert to the manner in which sports specificity has been applied in the realm of the four freedoms and competition law.

\subsubsection{Sports Specificity and Free Movements}

Article 45 of the TFEU establishes that no discrimination by origin will be allowed when it comes to measures affecting the free movement of workers. ${ }^{29}$ Discriminatory measures can still be justified, if the regulating Member state can invoke

limitations justified on grounds of public policy, public security or public health ...

Sports specificity could be viewed as either an additional element to the above-mentioned grounds, or an expression of public policy. ${ }^{30}$ The substantive legal test embedded in these grounds as well as in sports specificity is the same: proportionality.

In the realm of the four freedoms, the overwhelming majority of cases concern de facto discrimination. This is a highly amorphous concept, and case law evidences a continuing struggle by

\footnotetext{
28 The leading case in WTO law is the Appellate Body report on US-Gambling (available at https://docs.wto.org/dol2fe/Pages/FE_Search/FE_S_S006.aspx?Query=(@Symbol=\%20wt/ds285/ab/r*\%20not\%20rw*) $\&$ Language $=$ ENGLISH\&Context=FomerScriptedSearch\&languageUIChanged=true\#).

29 Football players have been assimilated to workers since the Bosman jurisprudence.

30 Compare the thoughts expressed in Weatherill (2017) in Chapters 5.5 and 7.3.
} 
the Court to come to grips with it and provide a meaningful test. ${ }^{31}$ The problem in a nutshell is this. De facto discrimination presents us with an information problem. The party possessing private information has little incentive to reveal the truth, when it knows it is in the wrong. The burden of proof though, is allocated to the party deprived of private information. It is thus, quite understandable why the CJEU (as many other courts) has struggled in its effort to develop a meaningful test to address this issue.

And yet, this might be an important issue in future regulation of football. The home-grown rule, it could be argued, is a case of de facto discrimination that has never been tried by the CJEU. UEFA might need to walk on the tightrope of de facto discrimination in the future as well when establishing rules on competitive balance.

\subsubsection{Sports Specificity and EU Antitrust Law}

Article 101.3 of the TFEU allows for justified deviations from the, in principle, prohibition of horizontal agreements, if certain conditions have been met. To avoid misunderstandings, we cite the full text of this provision:

The provisions of paragraph 1 may, however, be declared inapplicable in the case of:

- any agreement or category of agreements between undertakings,

— any decision or category of decisions by associations of undertakings,

- any concerted practice or category of concerted practices,

which contributes to improving the production or distribution of goods or to promoting technical or economic progress, while allowing consumers a fair share of the resulting benefit, and which does not:

(a) impose on the undertakings concerned restrictions which are not indispensable to the attainment of these objectives;

(b) afford such undertakings the possibility of eliminating competition in respect of a substantial part of the products in question.

Weatherill (2017) has expressed the view that the sport-specificity test applies to EU antitrust law both because of the Court of Justice of the European Union (CJEU) general approach, and as a result of the cross-cutting effect of Article 165 of the TFEU. In this vein, UEFA could argue that a practice, which seems to be restrictive of competition, is necessary for the organization of sport. It will be then for the Court to decide whether the practice falls under the ambit of Article 101.1 of the TFEU but is justified, or, as the Court already did in its Meca-Medina jurisprudence using the general competition law methodology applied in Wouters (C-309/99), it evades the applicability of Article 101.1 of the TFEU altogether.

In Weatherill's view, following the Meca-Medina cum Wouters-test, a practice that is necessary for the organization of football is not forbidden by Article 101.1 of the TFEU, and the question of justification under Article 101.3 of the TFEU does not even arise. Only if the practice is a restriction of competition within the meaning of Article 101.1 of the TFEU (because it is not necessary for the organization of sport) would the EU authorities look into Article 101.3 of the TFEU. In support of his view, he mentions the Commission Decision on collective sale of Champions League TV rights. The sale is not necessary to organize the sport, but it has economic benefits (lower transaction costs, improved brand identity) and so it is caught by Article 101.1, but it is exempted under Article 101.3 of the TFEU.

31 Compare the test employed by the CJEU in Dassonville (8/74), to that in Cassis de Dijon (102/78), to that in Keck and Mithouard (C-267 and 268/91). For a brief but comprehensive overview, see Weiler (2000). 
In AT.40208 International Skating Union's Eligibility Rules, ${ }^{32}$ the Commission left no doubt that this opinion is the right one. In $\$ 210$ held:

The Eligibility rules constitute rules related to the organisation of competitive sport. In MecaMedina, the Court of Justice ruled that such rules are generally subject to Union competition law. They may fall outside the application of Article 101 of the Treaty in certain circumstances, taking into account (i) the overall context in which the rules were taken or produce their effects and their objectives, (ii) whether the consequential effects restrictive of competition are inherent in the pursuit of the objectives and (iii) whether they are proportionate to them. (emphasis added)

This passage is self-interpreting. To remove any doubts though, that the sports specificity is factor that is to be considered under Article 101.1 of the TFEU, in $\$ \S 287-301$ of the same decision the Commission examined whether the Eligibility Rules that were found to violate Article 101.1 of the TFEU (since they were not necessary to achieve a sporting objective) could still be justified through recourse to Article 101.3 of the TFEU.

Now where does this all lead us? If say UEFA fails to defend its measures aiming to establish competitive balance under Article 101.1 TFEU, then it can always have a "second shot" by claiming exemption under Article 101.3 of the TFEU. There is thus a sequence between raising a sportsspecificity defense under Article 101.1 of the TFEU, and requesting an exemption under Article 101.3 of the TFEU. Of course, one might legitimately ask whether UEFA could invoke grounds under the latter that it did not include in its claims under the former. ${ }^{33}$ Even though similar arguments make logical sense, legally the two processes are distinct.

The function of sports specificity is thus clear. The test itself though, leaves, for the reasons discussed above, substantial discretion to the EU authorities the outcome of the exercise of which could be hard to predict. Indeed, reasonable minds could very well differ on the proportionality of actions aimed to achieve objectives expressed at a very aggregate level (e.g., sports integrity).

At this stage, European football is only taking its first steps towards meaningful regulation that will guarantee the introduction of competitive balance in institutional manner. The system described above leaves substantial discretion to the EU authorities, and, for the reasons discussed, a degree of uncertainty as to how it might be exercised. In what follows, we develop a framework that, while not questioning the primacy of EU law, will better serve the objective of predictability as to the consistency of the eventual interventions with EU law.

\section{Changing Lanes}

There are two problems with the approach followed so far to advance regulation of football in Europe. First, certainty is heavily undermined, since no insurance policy can be bought ex ante. UEFA cannot be sure that its interventions pass muster until the Commission and/or the CJEU have exercised their discretion. Now, this would not be too much of an issue if the application of the "sports specificity"test always led to predictable results. This is alas, not the case, and this brings us to the second problem. The current test is inherently indeterminate for the reasons that we have explained above.

Under the circumstances, one cannot exclude that things stay as they are. Conflicts will be resolved before the CJEU, and informal cooperation will provide UEFA with tolerance but no insurance policy. Things of course, could change drastically if the competence equilibrium between Member states and the European Union is altered. This is not in the cards for now.

32 http://ec.europa.eu/competition/antitrust/cases/dec_docs/40208/40208_1384_5.pdf

33 Jones and Kovacic (2017) take this discussion one step further and argue whether, in light of the current construction of Article 101.1 of the TFEU, and the embedded in Wouters reasonableness-test therein, it still makes sense to keep the door for exemptions under Article 101.3 of the TFEU. 
On the other hand, the recent UEFA initiatives on home-grown players, licensing and FFP, demonstrate an uneasiness with the current regulation of football. The presence of regulation in these three areas is proof of unhappiness with the pre-existing situation. And there is more. As recently, as end of April 2018, UEFA President Ceferin repeated that the quest for competitive balance tops his agenda for reform. ${ }^{34}$ Since the majority of UEFA members are EU football associations, his uneasiness with the current situation is shared ${ }^{35}$ by stakeholders who could (should?) ${ }^{36}$ be voicing the same concerns in Brussels (instead of or besides voicing them in Nyon).

The current piecemeal informal cooperation is hardly a recipe for success, if the current willingness to move forward were to translate to something tangible. A project of this endeavour requires a stable framework. The various options are briefly discussed in what now follows.

\subsection{The Options Available (if Formality Were Privileged)}

In principle, assuming football remains a support competence at the EU level, the following options are available to regulate it in comprehensive manner:

(a) Specific regulation of football (aided by enhanced cooperation);

(b) Formal exemption from antitrust prosecution.

If a specific regulation is privileged, then there is no need to do anything else. Specific regulation can, in principle, cover both EU antitrust- as well as four freedoms-related issues. Nothing else is needed.

Since the formal exemption can only concern antitrust issues, and because the four freedoms could come into play as well, it is probably wise to complement similar efforts with some additional mechanism. Alas, there is not much else UEFA could do. The proposal we advance in this paper is to request the establishment of a roundtable, which could serve as hothouse for future regulation. We detail it all in what now follows.

\subsection{Exemptions vs Sports-Specific Regulation}

Recall that recourse to Article 101.3 of the TFEU is warranted for the case under consideration only in case a measure was found to violate Article 101.1 of the TFEU. This, we could call the "worst case scenario", that is, the case where say UEFA decided to impose a salary cap or pooling of resources and the Commission thought it violated Article 101.1 of the TFEU.

In this case, UEFA could either litigate or request an exemption under Article 101.3 of the TFEU. Comfort letters cannot be issued anymore, as they would question the new regime of Regulation $1 / 2003$, which is an exceptions-regime, and was adopted precisely to put an end to "comfort letters". The only way the Commission can now give a nod to a restrictive agreement is either by decision of non-applicability under Article 101.1 of the TFEU, or by decision of exemption under Article 101.3 of the TFEU, or by an equivalent to a "business review letter", which is nevertheless adopted not just by Directorate General Competition, but by the college of Commissioners. This decision comes close to the old "comfort letters" is attackable before the European Courts. This was not the case of "comfort letters", which were informal letters that could not form the subject-matter of litigation.

\footnotetext{
34 Full text available at http://www.insideworldfootball.com/2017/09/15/ceferin-puts-ffp-competitive-balance-top-uefaagenda/

UEFA does not publish accounts of the negotiating record of its statutes. It is thus, absent anecdotal evidence, impossible to know if its initiatives are top-down (originating in the EU bureaucracy), or bottom-up (originating either in national football associations or in clubs associations/ECA).

36 We will return to this issue later when we discuss enhanced cooperation.
} 
The strength of arguments UEFA might possess notwithstanding, it would make better sense to request an exemption. This is so because, in this case, if granted, UEFA could count on the Commission's support, in the unlikely case that a party with legal interest would attempt to litigate the granting of exemption. If not granted, UEFA will be where it was in the first place, arguing that its measures are not in violation of Article 101.1 of the TFEU and/or should have been exempted anyway.

The Commission could always point to the self-executing character of antitrust exemptions, and it could thus refuse to accede to a similar request. UEFA should insist that formality of this sort is in everyone's interest, as it is around a formal exemption that the regulatory edifice will be built on.

What we are arguing here is, essentially, a plea for formal settlements. Informality comports severe risks. In this sense, a "business review letter" would be equally appropriate, since, like a formal exemption, it binds the Commission that has issued it (and, like a formal exemption, it does not bind the CJEU). ${ }^{37}$

UEFA could also contemplate the negotiation of sector-specific antitrust rules applicable only to football, as is the case for example with respect to farm goods. ${ }^{38}$ The problem with this approach is that UEFA would be forced to delve into a complicated political economy game, where various stakeholders have a seat in the negotiating table (being legally competent to do so). UEFA will have to negotiate with multiple partners instead of facing only the Commission, and, as a result, negotiating costs could increase. The upshot of course, is that if sports-specific regulation has been achieved, then there is no need for anything else.

There are other considerable advantages associated with sports-specific regulation. The framework established will enjoy the legitimacy that any EU act enjoys, since it will be the outcome of a process with embedded institutional checks and balances.

\subsection{Exemptions vs Sports-Specific Regulation Redux (Brussels Enhanced)}

If a sports-specific regulation is privileged, then the relative input of Member states and UEFA will be drastically affected. UEFA of course, is not a Member state, so its input in the process can only be indirect. True, in practice, input from similar sources happens, and is often indeed encouraged. UEFA nevertheless, cannot be a decisive voice in this process, which will be dominated by the Member states and the EU institutions.

The choice of legal instrument thus, affects the identity of the players who will take a seat around the table to decide the issue. UEFA will have direct input in case the request is for an inapplicability (of Article 101.3 of the TFEU) decision, or an exemption/business review letter under Article 101.3 of the TFEU. The intensity of participation of UEFA will be drastically reduced in case the option leading to a sports-specific regulation is privileged.

The role of UEFA input could be further reduced if the EU Member states opted to include football regulation in one of the enhanced cooperation initiatives.

Article 20 of the Treaty on the European Union (TEU) provides a platform for enhanced cooperation across Member states, that is, in areas where the European Union has no exclusive competence. These are the areas mentioned in Articles 4 and 6 of the TFEU. ${ }^{39}$ Article 6(e) of the

\footnotetext{
37 Vermeersch (2007) has an elaborate proposal to this effect.

38 Council regulations 1184/2006/EC of 24 July 2006, and 1234/2007/EC of 22 October 2007.

39 Woutres and Schmitt (2018) discuss this issue in detail.
} 
TFEU mentions sport, so enhanced cooperation, assuming the conditions of Article 20 of the TEU have been met, ${ }^{40}$ in the realm of sports cannot be outright excluded.

Enhanced cooperation could increase the probability for sports specific regulation. It is remarkable that so far, EU Member states have not even entertained the issue. In fact, there is no evidence of concertation between them at the UEFA/FIFA stage either. EU Member states have so far refrained from even tabling joint proposals.

Realistically thus, one should not expect sports specific regulation any time soon. The initiative for now is with the UEFA, hence it is likelier to see a request for exemption.

\subsection{EU-UEFA Roundtable to Pre-empt (Avoid Going Out on a Limb)}

Sports specificity is relevant to the scrutiny of UEFA statutes under both EU antitrust, as well as free movements law. There is one difference though, and a notable one: whereas under antitrust law exemptions from prosecution are possible (Article 101.3 of the TFEU) ${ }^{41}$ this is not the case with respect to violations of any one of the four freedoms.

Issues that do not come under antitrust exemption could be negotiated through direct contacts between the two bureaucracies. A permanent roundtable should be established to this effect aiming to avoid unnecessary and costly surprises. This endeavor could also serve as ante-chamber to formal agreements, some sort of a "regulatory hothouse" that would discuss all sorts of issues that come up in practice and surprise the legislator, and that could eventually find their way into by-laws.

\subsection{Preparing the Menu for the Roundtable}

The discussion above regarding enhanced cooperation finds, in principle, application here as well. Since the roundtable is informal though, it is highly unlikely that enhanced cooperation as per Article 20 of the TEU will see the light of day, as other looser forms of cooperation might be privileged.

\section{Open a Channel Between Nyon and Brussels}

UEFA and the EU bureaucracy have comparative advantage in different issues, and the former must observe the law of the latter. The communication channel between Nyon and Brussels has not been always functioning efficiently so far. This paper has aimed to provide a few ideas that could help change this picture for the benefit of all wanting to improve the current state of regulation of European football.

The question the two partners should ask is whether they should be dancing by themselves, or whether they should tango. As things stand, UEFA has the initiative and the European Union, the last word. If as reaction to Ceferin's recent statements, Brussels wants to strike first with no input from non-EU federal associations and/or UEFA, then it could do so through enactment of sports specific regulation.

40 There is a plethora of writings on practice in the realm of enhanced cooperation. Kroll and Leuffren (2014), and Cantore (2011) provide between them a comprehensive account.

41 Possible yes, probable no. Who, other than an aggrieved competitor, would have the incentive to litigate an exemption? Who is UEFA's competitor when it comes to organizing pan-European football competitions? None, is the short answer. Of course, potential (as opposed to actual) competitors might legitimately act as complainants. With the end of the Gandalf project though, there is no one in the horizon at this stage. For earlier practice in the realm of adjudication of antitrust exemptions, see Communication from the Commission, Notice, Guidelines on the Application of Article 81(3) of the Treaty, 2004/C 101/08, OJ C 101/97 of 24 April 2004. Very very few cases have been litigated in recent years as well. Indeed, in the most recent Van Bael \& Bellis Newsletter (March 2018) only one case of de facto exemption is mentioned. Securing thus, an exemption would amount for UEFA almost a guarantee for non-prosecution. 
There is undeniably merit in cooperating because of the complementary expertise that the two actors have developed through the years, even if sports specific regulation is eventually privileged. The European Union will be arriving at informed solutions. And UEFA will have been taught a valuable lesson in terms of involving all potentially interested stakeholders, in terms of checks and balances, as well as in terms of corporate governance that observes accountability.

The discussion above helps explain the current stalemate. UEFA has absolutely no incentive to push national associations towards seeking sports-specific regulation at EU level. By doing that, it will be eviscerating its own relevance. On the other hand, national associations have little incentive to ask for sports-specific regulation, since they will ipso facto be transferring (part of) their competence to regulate football to EU institutions (and they might be harming their relationship with UEFA and the non-EU national associations participating therein). ${ }^{42}$ Finally, the EU institutions cannot "nudge" stakeholders towards one or the other direction, as football is only support competence in EU law. The most realistic option it seems is that offered through the current EU antitrust regulatory framework. Recall nevertheless, that this option does not offer any protection for legislative initiatives concerning the four freedoms. A roundtable emerges as the natural complement to this endeavour.

42 National associations are very different from each other. Some have managed to establish very successful leagues, truly global brands, and some not. And since football is national competence, it is highly unlikely that they all have to observe the same regulatory constraints. These and similar differences between them might help explain why they have not found in their interest so far to converge within the EU-framework, adopt common positions and speak with one voice at the UEFA-level. On the other hand, the UEFA administration has strong incentives to further "cultivate" this approach, since, in this constellation, its own bargaining position is not eviscerated (it does not have to face an EU behemoth). 


\section{References}

van Bael, Ivo, and Jean-François Bellis. 2018. Van Bael \& Bellis on Competition Law Newsletter, March 2018 : Brussels, Belgium.

Cantore, Carlo Maria. 2011. We're One but we are not the Same, Enhanced Cooperation and the Tension between Unity and Asymmetry in the EU, Perspectives on Federalism, vol. 3, available at http://on-federalism.eu/attachments/103_download.pdf

Downward, Paul, and Geoff Pearson. 2014. An Assessment of the Compatibility of UEFA's Home Grown Player Rule with Article 45 TFEU, European Law Review, 39: 493-510.

García, Borja. 2007. UEFA and the European Union: From Confrontation to Cooperation,

Journal of Contemporary European Research, 3(3): 202-223.

Kroll, Daniela A., and Dirk Leuffren. 2015. Enhanced Cooperation in Practice, an Analysis of Differentiated Integration in EU Law, Journal of European Public Policy, 22: 353-373.

Leeds, Michael A., and Peter von Allmen. 2016. The Economics of Sports, Fifth Edition, Routledge: New York City, New York.

Lindström-Rossi Lenita, Sandra de Waele, amd Dovile Vaigauskaite. 2005. Application of EC Antitrust Rules in the Sport Sector : an Update, Competition Policy Newsletter, no 3, pp. 72-77.

Jones, Alison, and William E. Kovacic. 2017. Identifying Anticompetitive Agreements in the United States and the European Union: Developing a Coherent Antitrust Analytical Framework, Antitrust Bulletin, 62: 254-293.

Mataija, Mislav. 2016. Private Regulation and Internal Market, Oxford University Press: Oxford, United Kingdom.

Miège, Colin. 2000. Les Organisations sportives et l'Europe, INSEP: Paris, France

Parrish, Richard. 2003. Sports Law and Policy in the European Union, Manchester

University Press: Manchester, United Kingdom.

Szymanski, Stefan, and Andrew Zimbalist. 2005. National Pastime. Brookings Institution Press: Washington, DC.

Szyszczak, Eika. 2018. Competition and Sport: No Longer Special? Journal of European Competition Law and Practice, 9: 188-196.

Taylor, Matthew, and Pierre Lanfranchi. 2015. Mobility, Migration and History: Football and early Transnational Networks, Routledge: London, United kingdom.

Vermeersch, An. 2007. All's Fair in Sport and Competition? The Application of EC Competition Rules to Sport, Journal of Contemporary European Research, 3: 238-254.

Weatherill, Stephen. 2017. Principles and Practice in EU Sports Law, Oxford University Press: Oxford, United Kingdom.

Weiler, Joseph H.H. 2000. The EU, the WTO and the NAFTA: Toward a Common Law of International Trade, Oxford University Press: Oxford, United Kingdom.

Wouters, Jan, and Pierre Schmitt. 2018. Equality Among Member States and Differentiated Integration in the EU, pp. 43-82 in L.S Rossi and F. Casolari (eds.), The Principle of Equality in EU Law, Springer Verlag: Berlin, Germany. 


\section{Author contacts:}

\section{Petros C. Mavroidis}

Columbia Law School and University of Neuchâtel

Edwin B. Parker Professor of Law at Columbia Law School

Jerome Greene Hall, Room 734

435 West 116th Street

New York, NY 10027

Email: pmavro@law.columbia.edu

Email: Petros.Mavroidis@unine.ch 